\title{
GAMBARAN RADIOLOGIS PADA BIDANG NEUROLOGIS TUMOR OTAK
}

\section{Zanetha Mauly Ilawanda, Genta Faesal Atsani}

Fakultas Kedokteran, Universitas Mataram

Email: zanethailawanda@gmail.com gentafaesal16@gmail.com

\begin{abstract}
Abstrak
Seiring dengan bertambahnya usia harapan hidup dan kemajuan teknologi kedokteran, insidensi tumor otak terus meningkat. Tumor otak dapat mengakibatkan terjadinya perubahan status mental, defisit neurologis, serta menciptakan beban sosial yang besar. Insidensi tumor otak jinak adalah sebesar $71 \%$ dan tumor otak jinak ini berkembang dua kali lebih sering pada wanita dibandingkan pada laki - laki. Mendiagnosis tumor otak diperlukan pemeriksaan radiologi yang dapat dengan cepat mendiagnosis tumor otak dan harus segera dilakukan. Pencarian sumber dilakukan di portal online publikasi jurnal sebanyak 20 sumber yang berasal dari MedScape, Google Scholar dan Nation Center for Biotechnology Information/ NCBI dengan kata kunci "brain tumor" dan "radiology of brain tumor". Tumor otak menyebabkan timbulnya gangguan neurologis secara progresif. Gangguan neurologik pada tumor otak biasanya disebabkan oleh dua faktor, yaitu gangguan fokal akibat tumor dan kenaikan tekanan intrakranial. Teknik radiologi yang paling umum digunakan adalah T1 / T2-Weighted MRI, Spektroskopi MR, Difusi MRI, Perfusi MRI, dan CT Scan Tumor Otak. MRI adalah instrumen yang kuat dan fleksibel untuk mengevaluasi pasien dengan tumor otak primer. Integrasi kriteria RANO ke dalam evaluasi pengobatan membantu mengurangi penghentian dini terapi yang efektif karena perubahan pencitraan terkait pengobatan.
\end{abstract}

Kata Kunci: tumor otak; tatalaksana; radiologi

\begin{abstract}
Along with increasing life expectancy and advances in medical technology, the incidence of brain tumors continues to increase. Brain tumors can cause changes in mental status, neurological deficits, and create a large social burden. The incidence of benign brain tumors is $71 \%$ and these benign brain tumors develop twice as often in women as in men. Diagnosis brain tumors requires radiological examinations that can quickly diagnose brain tumors and must be done immediately. Source searches were carried out on the online portal of journal publications as many as 20 sources from MedScape, Google Scholar and the Nation Center for Biotechnology Information / NCBI with the keywords "brain tumor" and "radiology of brain tumor". Brain tumors cause progressive
\end{abstract}


neurological disorders. Neurologic disorders in brain tumors are usually caused by two factors, namely focal disturbances due to tumors and increased intracranial pressure. The most commonly used radiological techniques are T1/T2-Weighted MRI, MR Spectroscopy, Diffusion MRI, Perfusion MRI, and Brain Tumor CT Scan. MRI is a powerful and flexible instrument for evaluating patients with primary brain tumors. Integration of the RANO criteria into treatment evaluation helps reduce premature discontinuation of effective therapy due to treatment-related imaging changes.

Keywords: brain tumor; governance; radiology

Diterima: 12-11-2021Ｄirevisi: 12-12-2021Ｄiterbitkan: 20-12-2021

\section{Pendahuluan}

Dengan perpanjangan harapan hidup dan kemajuan teknologi medis, kejadian tumor otak meningkat. Tumor otak dapat menyebabkan perubahan status mental, defisit neurologis, dan menyebabkan beban sosial yang sangat besar. Di Amerika dan Eropa, kejadian tumor otak meningkat dari 17,6 per 100.000 orang menjadi 22,0 per 100.000 penduduk. Ada sekitar 18.500 kasus baru terdiagnosis tumor otak primer di Amerika Serikat setiap tahun. Angka kematian kasus ini cukup tinggi, 3 dalam 5 tahun\% Tingkat kelangsungan hidup. Di Republik Korea, sebanyak 10.004 tumor otak didiagnosis pada populasi 49,9 juta pada tahun 2010, dimana 601 (6\%) terjadi pada anak di bawah usia 19 tahun. Tingkat kejadian adalah $38,6 \%$ untuk pria dan $61,4 \%$ untuk wanita. Insiden tumor otak jinak adalah $71 \%$, dan insiden tumor otak jinak ini pada wanita dua kali lipat dari pria (Jung, et al., 2013).

Kejadian berdasarkan lokasi asal (asal tumor) yaitu meninges (33\%), parenkim otak $(29,8 \%)$, sadel $(21,8 \%)$, saraf spinal dan saraf kranial $(15,4 \%)$. Walaupun tumor otak primer dan metastatik menyebabkan morbiditas dan mortalitas yang signifikan, namun masih kurangnya informasi epidemiologi tumor otak, karena di beberapa negara, termasuk Indonesia, pendataan kasus tumor otak masih belum wajib. Selain itu, catatan tumor otak sering terbatas pada tumor otak ganas, sehingga tumor otak jinak sering diabaikan. Beberapa negara (seperti Spanyol, Italia, dan Prancis) juga menyediakan data yang berguna, tetapi hanya sedikit survei yang dilakukan mengenai informasi klinis dan biologis.

Pada tahun 2016, Organisasi Kesehatan Dunia (WHO) mengklasifikasikan tumor sistem saraf pusat (SSP) berdasarkan nomenklatur molekuler baru dan karakteristik histologis. Gambaran histologis didasarkan pada kesamaan penampakan sel tumor dan sel otak normal. Misalnya, glioma yang selnya mirip astrosit akan menjadi astrositoma, tetapi jika selnya mirip oligodendrosit akan menjadi oligodendroglioma. (Comelli, et al., 2017).

Tumor otak dapat dibagi menjadi tumor otak primer dan sekunder. Tumor otak primer adalah tumor otak yang berkembang dari sel-sel otak itu sendiri, sedangkan tumor otak sekunder adalah tumor otak yang bersifat sekunder atau bermetastasis dari tumor di 
bagian tubuh lain. Kebanyakan tumor yang bermetastasis ke otak adalah tumor payudara, ginjal, paru-paru, melanoma, dan kolorektal. Glioma dan meningioma adalah kasus tumor otak yang paling umum. Sepertiga dari tumor otak primer yang didiagnosis setiap tahun adalah glioma. Glioblastoma adalah glioma yang paling ganas.

Dalam sebuah studi populasi di Inggris, 4 dari 100.000 orang menderita glioblastoma setiap tahun. Usia onset glioblastoma tertinggi adalah 63 tahun, tetapi dapat terjadi pada semua usia. Glioma infiltrasi atau difus termasuk astrositoma dan oligodendroglioma, yang merupakan jenis tumor otak yang paling umum. Bailey dan Cushing pertama kali mengklasifikasikan tumor ini berdasarkan pola diferensiasi sel pada tahun 1926, dan metode ini telah diperbaiki selama beberapa dekade menggunakan fitur histopatologi untuk klasifikasi, grading, dan prognosis. Meningioma juga merupakan salah satu jenis tumor otak primer yang paling umum. Meningioma biasanya didiagnosis di atas usia 60 tahun, dan insidennya meningkat seiring bertambahnya usia. Meningioma jarang terjadi pada anak-anak, dan insiden pada wanita dua kali lipat dari pria (Comelli, et al., 2017).

Diagnosis tumor otak memerlukan pemeriksaan radiologi, yang dapat dengan cepat mendiagnosis tumor otak dan harus segera dilakukan. Menurut pedoman tahun 2017 dari National Institute of Health and Care Excellence (NICE), jika tidak ada kontraindikasi, dianjurkan untuk melakukan pemindaian resonansi magnetik (MRI) atau CT scan otak. CT scan atau MRI dengan kontras akan memberikan gambaran yang lebih rinci tentang keberadaan tumor otak untuk membantu menentukan jenis tumor dan merencanakan pembedahan dan terapi radiasi. Teknologi pencitraan juga berperan penting sebagai penanda prognostik dalam uji klinis tumor otak. Standar yang banyak digunakan didasarkan pada penilaian respons kelompok kerja neuro-onkologi, terutama berdasarkan MRI yang disebut penilaian respons neuro-onkologi (RANO). Tomografi emisi positron (PET) juga memiliki potensi dalam keterbatasan MRI (Brennan, 2018).

\section{Metode Penelitian}

Penulisan jurnal ini menggunakan metode kualitatif dengan bersumber dari jurnal ilmiah dan pedoman pemerintah maupun instansi terkait yang relevan dan terfokus pada tumor otak dan gambaran radiologinya. Pencarian sumber dilakukan di portal online publikasi jurnal sebanyak 20 sumber yang berasal dari MedScape, Google Scholar (scholar.google.com) dan Nation Center for Biotechnology Information/ NCBI (ncbi.nlm.nih.gov) dengan kata kunci "tumor" dan "radiology of tumor".

\section{Hasil dan Pembahasan}

\section{A. Definisi}

Istilah "tumor otak" merujuk pada berbagai kelompok neoplasma yang berasal dari jaringan intrakranial, termasuk meningen (contoh: meningioma) dengan berbagai derajat keganasan, dimulai dari yang jinak hingga ganas atau agresif. Setiap jenis tumor memiliki karakteristik biologis, pengobatan dan prognosisnya sendiri, yang biasanya disebabkan oleh berbagai faktor risiko. Prognosis tumor otak sangat tergantung pada 
lokasi, sifat invasi dan biologi tumor. Menurut asal jaringannya, tumor otak dibagi menjadi dua kategori, yaitu tumor otak primer dan tumor otak sekunder atau metastatik. Tumor otak primer berasal dari berbagai jaringan intrakranial, termasuk neuron, sel glial, astrosit, dan meningen. Tumor otak sekunder adalah metastasis tumor primer di tempat lain, biasanya dari tumor primer ganas padat, seperti kanker paru-paru, kanker payudara, melanoma, dan kanker ginjal, serta keganasan hematologis, seperti limfoma dan leukemia. Transfer ini dapat menyerang parenkim otak, pia mater dan dura mater (Brat \& Perry, 2010).

\section{B. Etiologi}

Etiologi tumor otak adalah perubahan genetik yang menyebabkan ketidakseimbangan onkogen dan tumor suppressor genes. Etiologi pasti yang dapat menyebabkan perubahan genetik ini belum diketahui. Tumor otak ada yang berasal dari jaringan otak sendiri (tumor otak primer), ada juga yang berasal dari tumor pada organ lain yang menyebar ke otak (tumor otak sekunder). Tumor otak primer terjadi akibat perubahan genetik pada sel di jaringan otak, yang menyebabkan sel tersebut tumbuh tanpa terkendali. Penyebab perubahan genetik ini sendiri belum diketahui dengan pasti. Meski begitu, ada beberapa faktor yang diduga dapat meningkatkan risiko seseorang mengalami tumor otak, antara lain: Paparan radiasi, Usia, Keturunan, Kelainan genetik. Sedangkan tumor otak sekunder, terjadi akibat adanya sel kanker dari bagian tubuh lain yang menyebar (metastasis) ke jaringan otak. Berikut ini adalah beberapa jenis kanker yang bisa menyebabkan tumor otak sekunder: (1) Kanker paru-paru, (2) Kanker payudara (3) Kanker usus, (4) Kanker ginjal, (5) Kanker kulit melanoma.

C. Epidemiologi

Kanker otak meliputi sekitar 85-90\% dari seluruh kanker susunan saraf pusat. Di Amerika Serikat in- sidensi kanker otak ganas dan jinak adalah 21.42 per 100.000 penduduk per tahun (7.25 per 100.000 penduduk untuk kanker otak ganas, 14.17 per 100.000 penduduk per tahun untuk tumor otak jinak). Angka insidens untuk kanker otak ganas di seluruh dunia ber- dasarkan angka standar populasi dunia adalah 3.4 per 100.000 penduduk. Angka mortalitas adalah 4.25 per 100.000 penduduk per tahun. Mortalitas lebih tinggi pada pria. Data cancer registry dari RSK Dharmais, RSCM, RS Persahabatan, IAPI, KPKN.Dari seluruh tumor primer susunan saraf pusat, astrositoma anaplastik dan glioblastoma multiforme (GBM) meliputi sekitar 38\% dari jumlah keseluruhan, dan meningioma dan tumor mesenkim lainnya $27 \%$. Sisanya terdiri dari tumor otak primer yang bervariasi, meliputi tumor hipofisis, schwannoma, limfoma SSP, oligodendroglioma, ependimoma, astrositoma derajat rendah, dan meduloblastoma (Herholz, 2017).

D. Patofisiologi

Tumor otak dibagi ke dalam dua kelompok besar, yaitu tumor otak primer dan tumor otak sekunder atau metastasis (Kemenkes RI, 2019). Tumor otak primer berasal dari berbagai jaringan intrakranial, termasuk neuron, sel glial, astrosit, dan meningen. Mekanisme terjadinya tumor otak primer masih dalam perdebatan, namun terkait dengan mutagen yang terpapar radiasi dan menyebabkan kerusakan struktural pada sel-sel otak. 
Saat terpapar, sel mengalami mekanisme adaptasi seluler, sehingga terjadi perubahan morfologi sel otak. Ketika terus menerus terkena radiasi atau mutagen, sel-sel otak akan mengalami perubahan ireversibel, yang menyebabkan mutasi DNA. Dalam hal ini juga akan terjadi inaktivasi tumor supresor gen dan aktivasi onkogen yang akan menyebabkan pembelahan sel otak menjadi tidak normal, disertai dengan penurunan mekanisme kematian sel (apoptosis). Peristiwa ini nantinya akan memicu perkembangbiakan sel-sel otak, yang kemudian dapat berkembang menjadi tumor otak (Price dan Wilson, 2013; (Chen, 2020).

Riwayat genetik juga kemungkinan sangat berperan dalam terjadinya tumor otak misalnya pada neurofibromatosis tipe 1 dan 2 (Priyanto et al, 2019). Tumor otak sekunder adalah metastasis dari tumor primer di tempat lain, menyebar melalui aliran darah, dan kemudian menembus dinding pembuluh darah. Transfer ini dapat menyerang parenkim otak, pia mater dan dura mater. Biasanya berasal dari tumor primer ganas padat, seperti kanker paru-paru, kanker payudara, melanoma, dan kanker ginjal, serta keganasan hematologi, seperti limfoma dan leukemia (Kemenkes RI, 2019).

Tumor otak menyebabkan timbulnya gangguan neurologis secara progresif. Gangguan neurologic pada tumor otak biasanya disebabkan oleh dua faktor, yaitu gangguan fokal akibat tumor dan kenaikan tekanan intracranial (Price dan Wilson, 2013). Gangguan fokal terjadi apabila terdapat penekanan pada jaringan otak dan infiltrasi atau invasi langsung pada parenkim otak dengan kerusakan jaringan neural. Perubahan suplai darah akibat tekanan tumor yang bertumbuh menyebabkan nekrosis jaringan otak. Terjadinya kompresi, invasi tumor sampai dengan substansia gresia otak, dan perubahan suplai darah ke jaringan otak akan bermanifestasi pada serangan kejang (James dan Varelas, 2011). Peningkatan tekanan intracranial dapat disebabkan oleh beberapa faktor yaitu bertambahnnya massa dalam tengkorak, terbentuknnya edema disekita tumor dan perubahan sirkulasi cairan serebrospinal (Price dan Wilson, 2013). Hal ini dapat menyebabkan peregangan pada meningens sehingga terjadi aktivasi mekanoreseptor yang memengaruhi kemoresptor yang berakibat timbulnya gejala mual dan muntah (Chen, 2020). Bertambahnya massa tumor pada otak dapat memicu pergeseran atau herniasi jaringan di bawah falx cerebri, melalui tentorium cerebelli, atau melalui foramen magnum. Obstruksi vena dan edema akibat kerusakan sawar darah otak akan menimbulkan peningkatan volume dan tekanan intracranial. Tumor yang berdekatan dengan ventrikel ketiga dan keempat dapat menghalangi aliran cairan serebrospinal, yang menyebabkan hidrosefalus obstruktif. Selain itu, tumor menghasilkan pembuluh darah baru (angiogenesis) (Lo, 2019).

E. MRI Dalam Mendiagnosis Tumor Otak

\section{T1 / T2-Weighted MRI}

MRI sangat sensitif terhadap perubahan patologis parenkim normal dan telah menjadi alat diagnosis penting dalam evaluasi tumor intrakranial. MRI memungkinkan penentuan lokasi lesi yang akurat, luas tumor, efek massa, atrofi, dan perdarahan subakut atau kronis, dan perbedaan yang akurat antara struktur vaskular dan parenkim yang berdekatan (Leung et al., 2014). Pemindaian MR tipikal untuk pasien dengan tumor otak 
mencakup T1 / T2-weighted, fluid-attenuated inversion recovery (FLAIR), dan gambar postcontrast T1-weighted (Gambar 2).
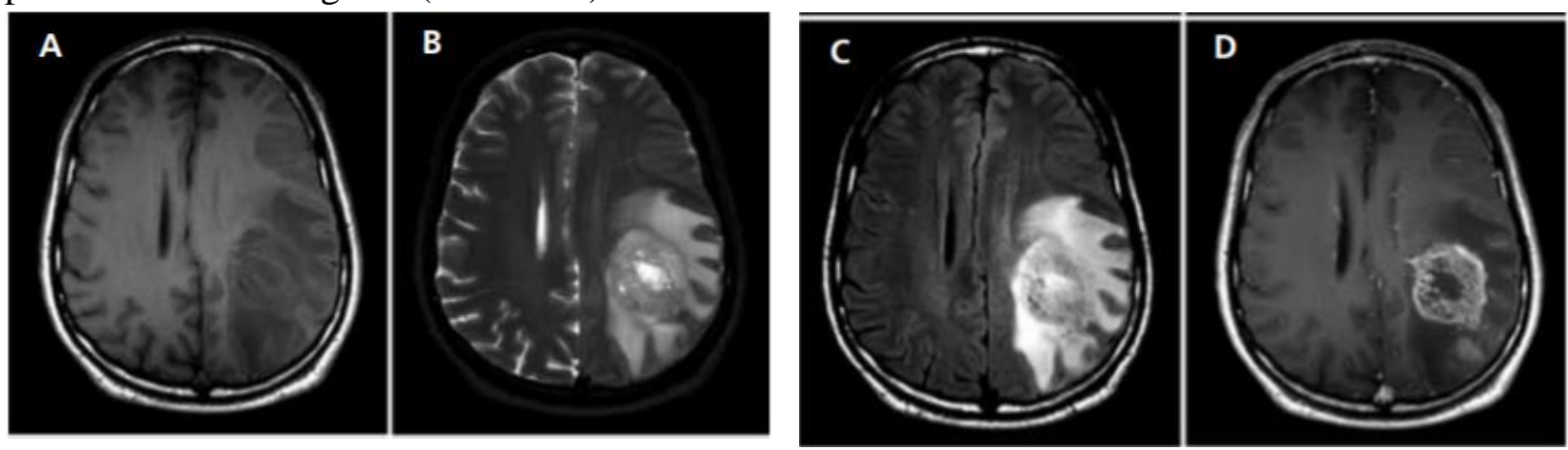

Gambar 1. T1 / T2-weighted, fluid-attenuated inversion recovery (FLAIR), dan gambar postcontrast T1-weighted (Leung et al., 2014).

Gambar MRI menunjukkan massa besar pada pasien dengan hemiparesis di sisi kanan. (A) Gambar T1-weighted menunjukkan lesi hipointensitas di regio frontal-parietal kiri. (B, C) Gambar pemulihan inversi berbobot T2 dan cairan-dilemahkan menunjukkan lesi hiperintensitas heterogen dengan edema di sekitarnya. (D) Gambar T1-weighted dengan kontras menunjukkan lesi yang meningkatkan cincin heterogen, area kedua dari peningkatan posterior lesi mayor, dan edema vasogenik. Patologi konsisten dengan glioblastoma (Leung et al., 2014).

Gambar T1-weighted paling berguna untuk menggambarkan detail anatomi dan menunjukkan cairan serebrospinal dan sebagian besar tumor sebagai intensitas sinyal rendah, sedangkan area lemak dan perdarahan subakut tampak sebagai intensitas sinyal tinggi. Citra dengan pembobotan T2 lebih sensitif untuk deteksi lesi dan menunjukkan cairan serebrospinal dan sebagian besar lesi sebagai intensitas sinyal tinggi, sedangkan area perdarahan atau endapan hemosiderin kronis mungkin tampak sebagai sinyal rendah.Gambar FLAIR berbobot T2 dengan cairan serebrospinal sinyal rendah, sangat sensitif untuk deteksi patologi, dan menampilkan sebagian besar lesi, termasuk tumor dan edema, dengan intensitas sinyal yang lebih tinggi daripada gambar T2.Namun, fokus tumor pada gambar FLAIR atau T2 tidak dipisahkan dengan baik dari edema di sekitarnya, gliosis, atau perubahan iskemia. Gambar T1-weighted setelah peningkatan kontras umumnya memberikan lokalisasi yang lebih baik dari tumor nidus dan informasi diagnostik yang lebih baik terkait dengan tingkat tumor, kerusakan darah-otak, perdarahan, edema, dan nekrosis (Leung et al., 2014).

\section{Spektroskopi MR}

Spektroskopi resonansi magnetik (MRS) telah digunakan selama lebih dari 20 tahun. Bagi dokter karena memungkinkan karakterisasi biokimia non-invasif dari suatu wilayah yang ingin diamati. Hal ini karena tidak memerlukan perangkat lunak tambahan atau pemrosesan akhir yang memakan waktu.Beberapa parameter metabolik yang diinterogasi oleh MRS berguna dalam evaluasi tumor otak.Kebanyakan tumor otak biasanya terjadi penurunan pada Nacetyl aspartate (NAA), dan sering kali juga 
meningkatkan level cho-line (Cho), yang menyebabkan peningkatan rasio Cho / NAA.NAA diperkirakan berasal dari saraf dan mungkin menurun pada tumor otak karena digantikan oleh sel tumor baru.level Cho berasal dari kontribusi dari beberapa senyawa yang terlibat dalam sintesis dan degradasi membran fosfolipid, dan peningkatan kadar Cho diyakini disebabkan oleh pergantian membran yang tinggi pada tumor otak (Leung et al., 2014).

Perbedaan Gambaran MR Spektroskopi pada Tumor Primer (Meningioma) dengan Metastasis
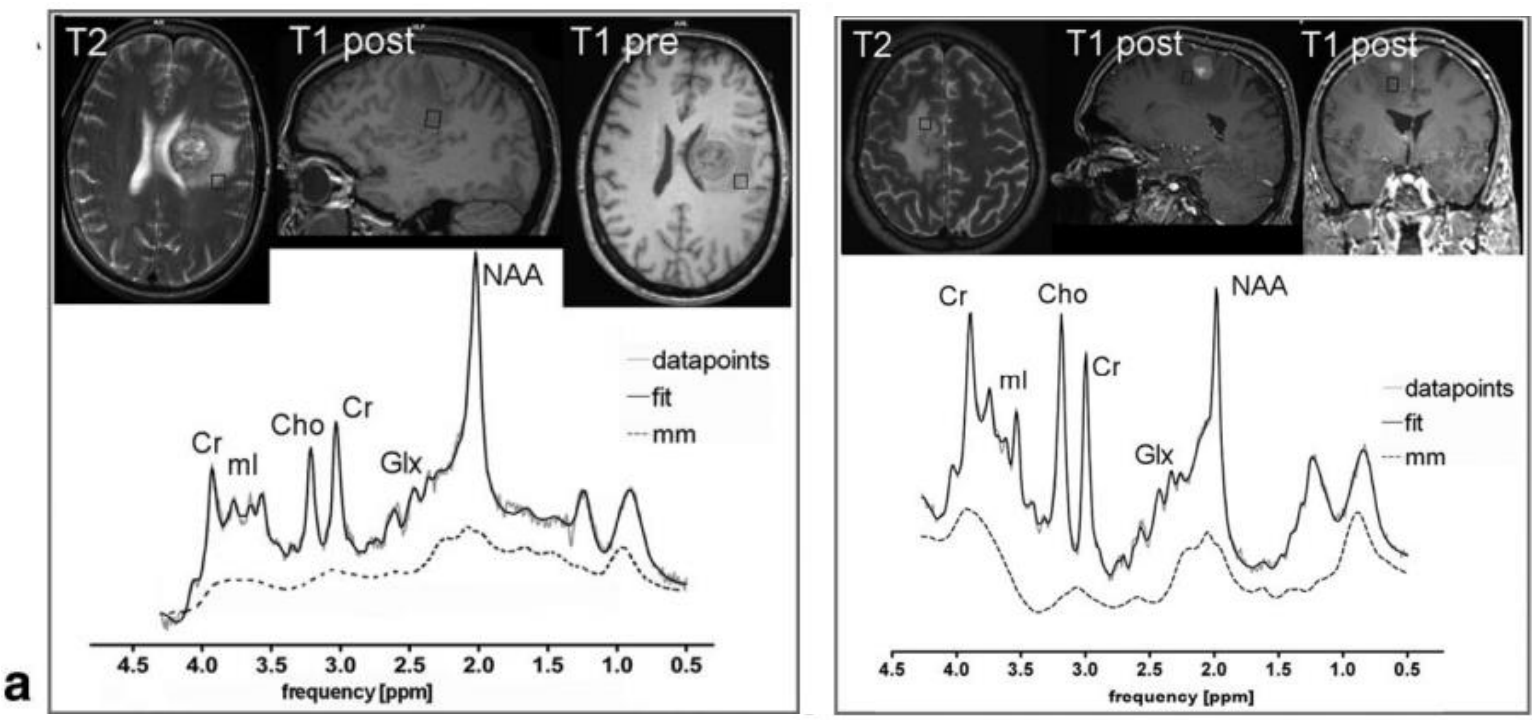

Gambar a. Gambaran MR Spektroskopi pada Meningioma dan Gambar C. Gambaran MR Spektroskopi pada Tumor Metastasis. Berdasarkan gambar diatas telah dilakukan uji oleh (Wijnen et al., 2012) apakah tingkat metabolit pada hasil MR Spektroskopi pada tumor metastasis dan meningioma berbeda ?. Terdapat perbedaan yang signifikan antara tumor ini Dengan ditemukan dalam evaluasi nilai tertinggi daerah edema peritumoral dengan Rasio mIpGly (myo-inositol dan glisin) dibandingkan $\mathrm{tCr}$ (kreatin dan fosfokreatin) lebih tinggi dan juga rasio tCho (gliserofosfokolin, dan phosphocholine) dibandingkan $\mathrm{tCr}$ (creatine dan phosphocreatine) lebih rendah pada meningioma dibandingkan dengan tumor metastasis.

Massa otak yang terlihat pada MRI konvensional dapat mencerminkan berbagai diagnosis banding, termasuk abses, demielinasi tumefaktif, dan lesi iskemik. Pembedahan untuk diagnosis dan penilaian tumor tetap menjadi standar emas. Namun, MRS dapat sangat membantu ketika tumor tidak dapat diakses melalui pembedahan atau tidak dapat direseksi sepenuhnya, karena dapat menunjukkan area yang kemungkinan besar memiliki derajat yang lebih tinggi oleh karena itu, menjadi mudah untuk menentukan target biopsi. Hal ini dapat sangat membantu untuk menentukan batas glioma infiltratif sehingga reseksi setengah total dapat dilaukan. Untuk membantu hal ini, penting untuk menetapkan penanda yang kuat (tumor marker) untuk jenis tumor yang berbeda. Salah satu proyek yang telah dicoba adalah Jaringan Internasional untuk Pengenalan Pola Tumor 
Menggunakan Resonansi Magnet (INTERPRET). 21 Studi INTERPRET telah mengumpulkan spektrum dari tumor otak dengan histologi yang diketahui dari berbagai institusi di seluruh Eropa untuk mengembangkan skema pengenalan data terkomputerisasi untuk membantu ahli radiologi dalam diagnosis dan penilaian (Leung et al., 2014).

\section{Difusi MRI}

Koefisien difusi semu (ADC) diperoleh dengan pencitraan berbobot difusi dan merupakan representasi kuantitatif dari mobilitas molekul air dalam jaringan yang dicitrakan.Ini sering berbanding terbalik dengan seluleritas jaringan, yang dapat menghambat pergerakan molekul air.Massa intrakranial yang berbeda memiliki nilai ADC yang berbeda, meskipun tumpang tindih, dan ini dapat menjadi tambahan yang berguna untuk MRI konvensional untuk diagnosis lesi.Teknik ini tidak digunakan secara luas, tetapi studi validasi prospektif sedang dilakukan (Leung et al., 2014). Pencitraan tensor difusi (DTI) mengukur pergerakan arah air setidaknya dalam 6 arah noncollinear. Turunan DTI dapat menyoroti pola saluran serat dalam 3 dimensi dan konektivitasnya. Untuk penyakit di mana saluran serat hancur, DTI dapat mencerminkan komponen histologis dan membedakan antara limfoma dan glioblastoma, dan antara meningioma dengan histologi WHO grade I dan meningioma atipikal. DTI juga telah digunakan untuk menggambarkan abses, metastasis kistik, dan glioblastoma nekrotik. Karena DTI memungkinkan visualisasi saluran serat, ini juga dapat membantu untuk perencanaan pembedahan, terutama ketika massa besar telah menggusur saluran serat. Ini mungkin juga berguna untuk pemahatan yang lebih tepat dari peningkatan radiasi dalam perencanaan perawatan radiasi yang dimodulasi intensitas (Leung et al., 2014).

Banyak minat telah ditunjukkan dalam menggunakan MRI difusi sebagai tambahan untuk mendiagnosis massa otak dan menilai tumor otak primer. MRI difusi tidak hanya tidak invasif, tetapi gambar dapat dengan mudah diperoleh pada mesin MRI konvensional.DTI mampu membedakan abses otak, glioblastoma nekrotik, dan metastasis kistik, yang semuanya dapat terlihat serupa pada MRI konvensional. Satu studi mensegmentasi setiap lesi menjadi zona nonoverlapping: kavitas kistik, tepi yang meningkat, dan area edema yang berbeda. Dengan menggunakan pengukuran dan pola berbeda yang dihasilkan dari pengukuran ini, yang diperoleh melalui pemrosesan data DTI, peneliti menemukan bahwa peneliti dapat membedakan glioblastoma dari metastasis dan perbedaan rongga kistik dapat digunakan untuk mengidentifikasi abses dari penyakit lain ini. DTI telah digunakan dengan cara yang sama untuk membedakan limfoma SSP primer dari glioblastoma dan atipikal dari meningioma klasik. Pengukuran yang diperoleh dari data DTI telah digunakan untuk mengukur seluleritas dan infiltrasi tumor dan untuk menentukan derajat tumor astrositik (Leung et al., 2014).

\section{Perfusi MRI}

Mekanisme di balik perfusi MR lebih kompleks daripada perfusi CT, sebagian besar karena hubungan nonlinier dari kontras konsentrasi bolus dengan atenuasi jaringan.Secara umum, proses perfusi dapat digunakan untuk menilai volume darah, kecepatan, dan oksigenasi.Dua metode dapat digunakan untuk mendapatkan informasi 
perfusi menggunakan agen kontras nondiffusible eksogen intravaskular, biasanya berbasis gad-olinium (Gd-DTPA) (Leung et al., 2014). Sama seperti teknik MRI yang disebutkan sebelumnya, dalam menggunakan perfusi MR sebagai tambahan untuk MRI konvensional dalam diagnosis lesi otak, sekali lagi karena ini noninvasif dan dapat memiliki implikasi prognostik dan pengobatan. Satu kelompok mampu menggunakan perfusi MR dalam membedakan beberapa entitas satu sama lain, termasuk, hemangioblastoma, abses, schwanomas, meningioma, limfoma SSP primer, dan metastasis. Penelitian telah menunjukkan beberapa manfaat menggunakan perfusi MR untuk membedakan tingkat glioma yang berbeda (Leung et al., 2014).
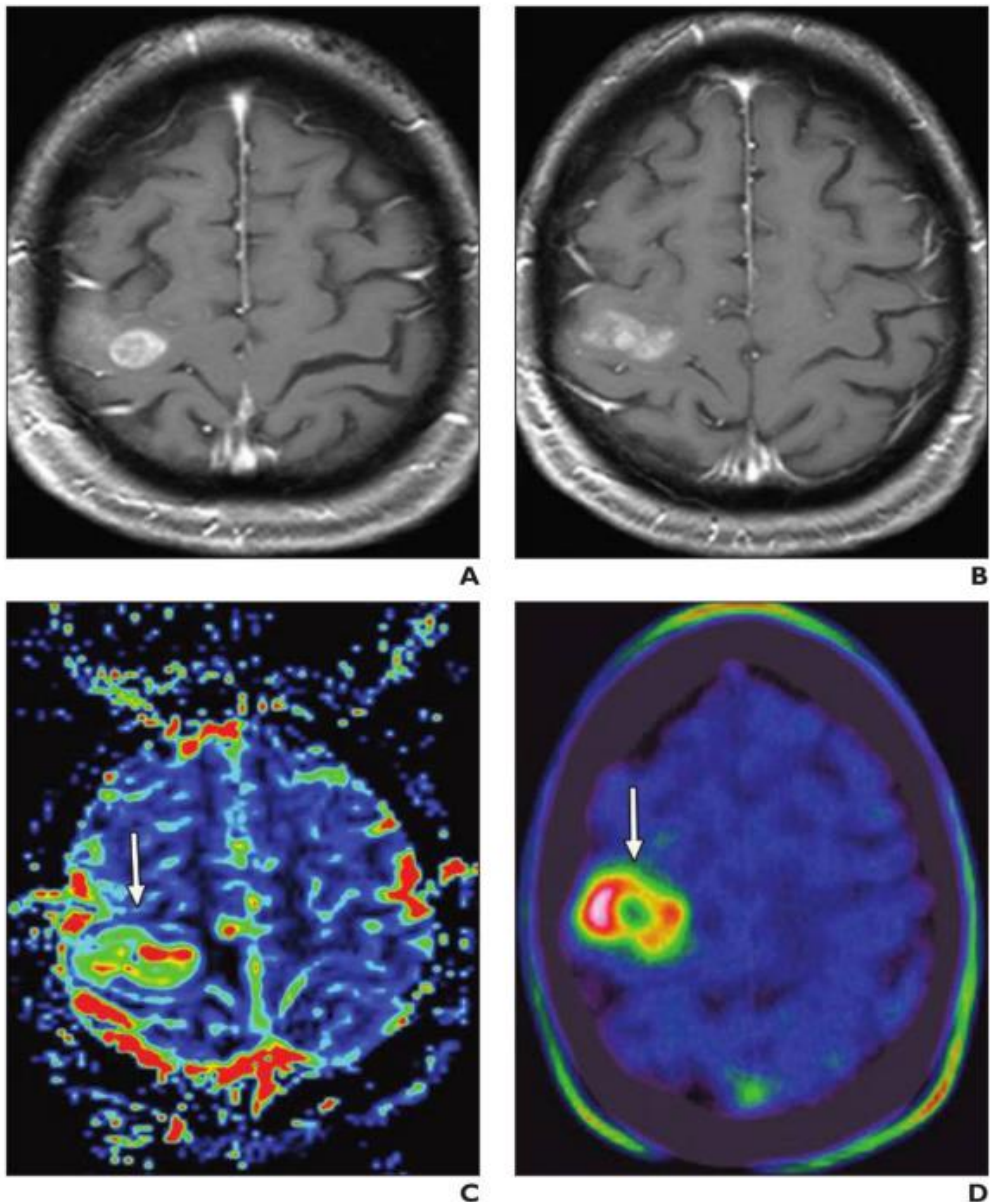

Gambar 2. Pasien dengan astrositoma derajat 4 yang dikonfirmasi secara histologis yang menjalani pemeriksaan kontras perfusi MRI dan PET (18F-fluorothymidine) A dan B, bagian berbeda) menunjukkan heterogenmeningkatkan lesi dengan hanya efek massa kecil. (C) berasal dari kontras kerentanan dinamis perfusi MRI (0,1 mmol gadobutrol yang disuntikkan pada $5 \mathrm{~mL} /$ dtk dengan saline flush 20-mL) berkorelasi dengan temuan PET (D), menunjukkan tumor (panah) dengan tingkat perfusi tinggi berdasarkan tinggi proliferasi (Essig et al., 2013) 


\section{CT Scan Tumor Otak}

Citra tumor otak dihasilkan melalui alat pemeriksaan yang disebut CT Scan secara spesifik untuk memperkuat diganosa dan mengetahui letak tumor otak tersebut. CT Scan merupakan alat diagnostik yang penting dalam evaluasi pasien yang diduga menderita tumor otak. Beberapa jenis tumor otak akan terlihat lebih nyata ketika pemeriksaan CT Scan disertai pemberian zat kontras dan deteksi tepi. Diagnosis penyakit tumor otak oleh para dokter menggunakan cara yang manual yaitu dengan melihat citra (image) yang dihasilkan oleh alat pencitraan medis. Hasil citra tersebut biasanya terdapat gangguan (noise) sehingga dibutuhkan sebuah alat bantu pengolahan citra berbasis komputer untuk dapat dijadikan sebagai salah satu acuan dalam mendiagnosis penyakit tumor otak (Egziabher and Edwards, 2013)

\section{F. Tatalaksana}

Pada penatalaksanan tumor otak, terdapat beberapa prinsip tatalaksana karena tumor otak merupakan penyakit yang kompleks dan tentunya memengaruhi quality of life dari penderita. Berikut prinsip terapi dalam medikamentosa dan nonmedikamentosa menurut Pedoman Nasional Pelayanan Kedokteran Tumor Otak, (Kemenkes 2019).

1. Tatalaksana Penurunan Tekanan Intrakranial

Pasien dengan tumor otak sering datang dalam keadaan neuroemergency akibat peningkatan tekanan intrakranial baik pada tumor otak primer maupun tumor metastasis. Hal ini terutama diakibatkan oleh efek desak ruang dari edema peritumoral atau edema difus.Gejala yang muncul tergantung dari lokasi dan ekstensi dari edema berupa nyeri kepala, mual dan muntah, perburukan gejala neurologis, dan penurunan kesadaran.Terapi medikamentosa yang diberikan untuk tumor otak berupa steroid, mannitol dan antikejang. Steroid yang direkomendasikan dan menjadi pilihan adalah deksametason. Untuk pasien yang sebelumnya tidak mengkonsumsi steroid diberikan dosis bolus $10 \mathrm{mg}$ intravena, kemudian dilanjutkan $6 \mathrm{mg}$ per oral atau intravena setiap 6 jam atau 4 kali sehari. Pemberian manitol tidak dianjurkan diberikan karena dapat memperburuk edema, kecuali bersamaan dengan deksametason pada situasi yang berat, seperti adanya peningkatan tekanan intrakranial yang berat dan pasca operasi. Manitol (20\%) dengan dosis 0,5-1,5 $\mathrm{gr} / \mathrm{kgBB}$ efektif dalam menurunkan tekanan intrakranial dalam waktu 15-35 menit setelah pemberian.

Kejang merupakan komplikasi yang sering terjadi dan memberikan efek yang merugikan, terjadi pada 20-40\% pasien dengan tumor otak. Oleh karena itu, pasien yang mengalami kejang karena tumor otak harus segera diberikan antikonvulsan atau obat antiepilepsi (OAE) untuk mencegah kejang berulang yang dapat menyebabkan perburukan kondisi. Ada beberapa hal yang harus dipertimbangkan dalam pemilihan obat, antara lain kemungkinan interaksi obat dengan kemoterapi dan deksamethason, terutama pada OAE generasi lama seperti fenitoin, karbamazepin, dan fenobarbital. Obat-obat tersebut dapat dipengaruhi dan dapat mengurangi tingkat sirkulasi obat-obat kemoterapi serta deksametason, sehingga menjadi kurang efektif. Kondisi yang harus diwaspadai adalah status epileptikus tonik klonik, yaitu bangkitan epileptik yang berlangsung secara terus menerus selama minimal 30 menit, atau berulang tanpa pulihnya kesadaran di antara 
bangkitan. Namun tata laksana sudah dapat diberikan jika kejang berlangsung lebih dari 5 menit dengan pemberian diazepam IV $0,15-0,2 \mathrm{mg} / \mathrm{kgBB} / \mathrm{kali}$, maksimal 10mg/kali, dapat diulang 1 kali. Selanjutnya jika masih terdapat kejang dapat diberikan terapi lini kedua, antara lain fenitoin, asam valproat, atau levetiracetam. Dosis fenitoin adalah IV 15-20mg/kgBB perlahan-lahan (kecepatan 50mg/menit) dosis tunggal, dapat diulang 5 $10 \mathrm{mg} / \mathrm{kgBB} / \mathrm{kali}$ intravena. Adapun dosis asam valproat adalah $20-40 \mathrm{mg} / \mathrm{kgBB}$ per oral, maksimal 3000mg/kali, sedangkan dosis levetiracetam adalah $20-60 \mathrm{mg} / \mathrm{kgBB}$ per oral, maksimal 4500mg/kali, dosis tunggal.

\section{Tata laksana Nyeri}

Pada tumor otak, nyeri yang muncul biasanya adalah nyeri kepala. Berdasarkan patofisiologinya, tatalaksana nyeri ini berbeda dengan nyeri kanker pada umumnya. Nyeri kepala akibat tumor otak bisa disebabkan akibat traksi langsung tumor terhadap reseptor nyeri di sekitarnya. Namun nyeri kepala tersering adalah akibat peningkatan tekanan intrakranial, yang jika bersifat akut terutama disebabkan oleh adanya edema peritumoral. Oleh karena itu tatalaksana utama bukanlah obat golongan analgesik, namun golongan glukokortikoid seperti deksametason atau metilprednisolon intravena atau oral sesuai dengan derajat nyerinya.

Pada tumor tertentu, gejala klinis nyeri biasanya bersifat lokal atau radikular ke sekitarnya, yang disebut nyeri neuropatik, seperti pada nyeri di daerah retroorbita, sela, sinuskavernosus, atau klivus Pada kasus ini pilihan obat nyeri adalah analgesik yang tidakmenimbulkan efek sedasi atau muntah karena dapat mirip dengan gejala tumor otak padaumumnya. Oleh karena itu dapat diberikan parasetamol dengan dosis $20 \mathrm{mg} / \mathrm{kg}$ berat badanperkali dengan dosis maksimal $4000 \mathrm{mg} / \mathrm{hari}$, baik secara oral maupun intravena sesuaidengan beratnya nyeri. Jika komponen nyeri neuropatik yang lebih dominan, maka golonganantikonvulsan menjadi pilihan utama, seperti gabapentin 600-1200 mg/hari, maksimal 3600mg/hari.

\section{Terapi Pembedahan pada Tumor Otak}

Pembedahan merupakan salah satu modalitas terapi yang sangat penting dalam terapi tumorotak baik untuk perbaikan kondisi klinis dan penegakan diagnosis patologi anatomi. Operasi pada kanker otak dapat bertujuan untuk menegakkan diagnosis yang tepat, menurunkan tekanan intrakranial, mengurangi kecacatan, dan meningkatkan efektifitas terapi lain. Reseksi tumor pada umumnya direkomendasikan untuk hampir seluruh jenis kanker otak yang operable. Pilihan meliputi total reseksi ketika layak, biopsy stereotaktik, biopsi terbuka/debulking. Waktu untuk dilakukan pembedahan pada umumya bersifat elektif dengan perencanaan, tetapi pada kondisi tertentu bisa menjadi tindakan emergensi/ cito jika didapatkan tanda-tanda tekanan intrakranial yang meningkat baik akibat langsung dari ukuran tumor yang besar dan adanya perdarahan disekitar tumor (intratumoral bleeding) ataupun akibat sekunder dari tumor karena edema otak yang tidak membaik dengan manajemen pengobatan dan obstruktif hidrosefalus. Tujuan secara umum operasi pengangkatan tumor adalah maksimal eksisi tanpa menyebabkan kerusakan fungsi otak jangka panjang atau dengan kata lain seorang dokter bedah harus mampu menentukan kapan harus menyisakan tumor jika diduga berisiko 
tinggi menyebabkan morbiditas pada pasien. Saat ini telah berkembang peralatan yang dapat memfasilitasi tindakan reseksi tumorsecara maksimal dan aman (maximum safe surgical resection) pada saat operasidiantaranya adalah intraoperative navigation dengan sistem frameless stereotaktik, pemantuan intraoperative (intraoperative monitoring), ultrasonography intraoperative, flourescence guided surgery, teknik pembedahan mikro menggunakan mikroskop, endoscopic neurosurgery, dan MRI intraoperatif.

4. Radioterapi Pada Tumor Otak

Radioterapi merupakan modalitas terapi penting pada kasus tumor SSP. Radioterapi dapat diberikan sebagai terapi definitif, ajuvan atau sebagai terapi paliatif. Dalam pemberian radioterapi pada tumor SSP, terdapat beberapa teknik radioterapi yang dapat diberikan:

a. Radioterapi 2-D, diberikan pada kasus definitif pada radiasi kraniospinal dan kasus paliatif seperti metastasis otak dan tulang.

b. Radioterapi 3-D konformal, merupakan terapi standar pada kasus tumor SSP dapat diberikan sebagai terapi definitif, ajuvan atau paliatif. Intensity modulated radiotherapy (IMRT) atau Volumetric modulated arc therapy (VMAT) diberikan pada tumor SSP yang letaknya berdekatan dengan jaringan sehat penting seperti batang otak, chiasma optik atau saraf optik.

c. Stereotacic radiosurgery $(S R S)$ diberikan pada kasus tumor SSP yang berukuran kecil (diameter $<3,5 \mathrm{~cm}$ ) dan letaknya tidak menempel dengan dengan jaringan sehat penting seperti batang otak, chiasma optik atau saraf optik.

d. Stereotacic radiotherapy (SRT) diberikan pada kasus tumor SSP yang tidak dapat dilakukan SRS, seperti diameter $>3,5 \mathrm{~cm}$ atau letaknya menempel dengan dengan jaringan sehat penting seperti batang otak, chiasma optik atau saraf optik.

e. Stereotacic body radiotherapy (SBRT) diberikan pada kasus metastases spinal dengan keterlibatan tumor maksimal 3 ruas vertebrae, namun tidak boleh lebih dari 2 ruas vertebrae berurutan. SBRT spinal diberikan pada kasus dengan potensi kuratif atau dapat diberikan pada kasus reiradiasi.

\section{Kemoterapi}

Kemoterapi bertujuan untuk menghambat pertumbuhan tumor dan meningkatkan kualitas hidup pasien semaksimal mungkin. Kemoterapi biasa digunakan sebagai kombinasidengan operasi dan/atau radioterapi. Dosis temozolomide (TMZ) pada saat diberikan concomitant dengan radiasi adalah $75-100 \mathrm{mg} / \mathrm{m} 2$, bila diberikan sebagai maintetance adalah 150-200 mg/m2. Tatalaksana tumor otak ganas dengan menggunakan kemoterapi seringkali terhambatakibat penetrasi kemoterapi sistemik yang rendah untuk menembus sawar darah otak.Pemberian kemoterapi intratekal merupakan salah satu upaya untuk memberikan agenantikanker langsung pada susunan saraf pusat.Kemoterapi intratekal dapat diberikan sebagaisalah satu tatalaksana leptomeningeal metastasis pada keganasan darah, seperti leukemia danlimfoma.Tindakan ini dilakukan melalui prosedur lumbal pungsi atau menggunakan Omayareservoir. 


\section{Dukungan Psikiatri}

Pasien dengan tumor otak dapat mengalami gangguan psikiatri hingga 78\%, baik bersifat organik akibat tumornya atau fungsional yang berupa gangguan penyesuaian, depresi, dan ansietas. Hal ini dapat menghambat proses tatalaksana terhadap pasien. Oleh karena itu, diperlukan pendampingan mulai dari menyampaikan informasi tentang diagnosis dan keadaan pasien (breaking the bad news) melalui pertemuan keluarga (family meeting) dan pada tahap-tahap pengobatan selanjutnya. Pasien juga dapat diberikan psikoterapi suportif dan relaksasi yang akan membantu pasien dan keluarga, terutama pada perawatan paliatif.

\section{Kesimpulan}

MRI adalah instrumen yang kuat dan fleksibel untuk mengevaluasi pasien dengan tumor otak primer. Integrasi kriteria RANO ke dalam evaluasi pengobatan membantu mengurangi penghentian dini terapi yang efektif karena perubahan pencitraan terkait pengobatan. Aspek lanjutan dari MRI, termasuk spektroskopi, difusi, dan perfusi, memberikan informasi dinamis yang terkait dengan respons dan perkembangan tumor otak. Upaya lebih lanjut untuk mengembangkan metrik jaminan kualitas dan algoritme interpretasi standar akan meningkatkan keseragaman karena komponen ini digunakan secara lebih luas. 


\section{BIBLIOGRAFI}

Jung KW, Ha J, Lee SH, Won YJ, Yoo H. An updated nationwide epidemiology of primary brain tumors in republic of Korea. Brain Tumor Res Treat. 2013;1(1):1623. Google Scholar

Comelli I, Lippi G, Campana V, Servadei F, Cervellin G. Clinical presentation and epidemiology of brain tumors firstly diagnosed in adults in the Emergency Department: a 10-year, single center retrospective study. Ann Transl Med. 2017;5(13):269. Google Scholar

Brennan PM. Tumours of the central nervous system. Surgery (Oxford). 2018;36(11):630- 6. Google Scholar

Egziabher, T. B. G. and Edwards, S. (2013) '済無', Africa's potential for the ecological intensification of agriculture, 53(9), pp. 1689-1699. Google Scholar

Indonesia, K. K. R. (2019) Pedoman Nasional Pelayanan Kedokteran Tumor Otak. Google Scholar

James, E. and Varelas, P. N. (2011) 'Brain Tumor and Seizures: Incidence, Pathophysiology, Diagnosis and Treatment', Management of CNS Tumors, (September 2011). doi: 10.5772/21100. Google Scholar

Kemenkes RI (2019) Profil Kesehatan Indonesia 2018 [Indonesia Health Profile 2018]. Google Scholar

Leung, D. et al. (2014) 'Role of MRI in primary brain tumor evaluation', JNCCN Journal of the National Comprehensive Cancer Network, 12(11), pp. 1561-1568. doi: 10.6004/jnccn.2014.0156. Google Scholar

Lo, B. M. (2019) Brain Neoplasms: Practice Essentials, Pathophysiology, Etiology, Medscape. Google Scholar

Priyanto, B., Rohadi and Siradz, B. F. (2019) 'Tumor Spinal Intradural Ekstramedula', Unram Medical Journal, 8(1), p. 25. doi: 10.29303/jku.v8i1.331. Google Scholar

Steven Chen (2020) Brain Neoplasms, Calgary Guide. Google Scholar

Egziabher, T. B. G. and Edwards, S. (2013) '済無No Title No Title', Africa's potential for the ecological intensification of agriculture, 53(9), pp. 1689-1699. Google Scholar

Indonesia, K. K. R. (2019) Pedoman Nasional Pelayanan Kedokteran Tumor Otak. Google Scholar

James, E. and Varelas, P. N. (2011) 'Brain Tumor and Seizures: Incidence, Pathophysiology, Diagnosis and Treatment', Management of CNS Tumors, (September 2011). doi: 10.5772/21100. Google Scholar

Kemenkes RI (2019) Profil Kesehatan Indonesia 2018 [Indonesia Health Profile 2018].

Essig, M. et al. (2013) 'Perfusion MRI: The five most frequently asked clinical questions', American Journal of Roentgenology, 201(3). doi: 10.2214/AJR.12.9544. Google Scholar

Wijnen, J. P. et al. (2012) 'Quantitative short echo time 1H MRSI of the peripheral 
edematous region of human brain tumors in the differentiation between glioblastoma, metastasis, and meningioma', Journal of Magnetic Resonance Imaging, 36(5), pp. 1072-1082. doi: 10.1002/jmri.23737. Google Scholar

\section{First publication right:}

Jurnal Syntax Fusion: Jurnal Nasional Indonesia

This article is licensed under:

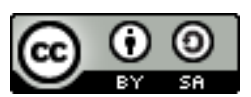

